A

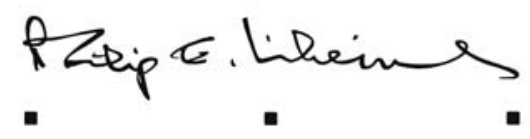

$\mathrm{B} \mathrm{O} \mathrm{O} \mathrm{K}$

The Philip E. Lilienthal imprint

honors special books

in commemoration of a man whose work

at the University of California Press

from 1954 to 1979

was marked by dedication to young authors

and to high standards in the field of Asian Studies.

Friends, family, authors, and foundations have together endowed the Lilienthal Fund, which enables the Press

to publish under this imprint selected books

in a way that reflects the taste and judgment

of a great and beloved editor. 
The publisher gratefully acknowledges the generous contribution to this book provided by the Philip E. Lilienthal Asian Studies Endowment Fund of the University of California Press Foundation, which is supported by a major gift from Sally Lilienthal. 
Vicarious Language 
ASIA: LOCAL STUDIES / GLOBAL THEMES

Jeffrey N. Wasserstrom, Kären Wigen, and Hue-Tam Ho Tai, Editors

I. Bicycle Citizens: The Political World of the Japanese Housewife, by Robin M. LeBlanc

2. The Nanjing Massacre in History and Historiography, edited by Joshua A. Fogel

3. The Country of Memory: Remaking the Past in Late Socialist Vietnam, by Hue-Tam Ho Tai

4. Chinese Femininities / Chinese Masculinities: A Reader, edited by Susan Brownell and Jeffrey N. Wasserstrom

5. Chinese Visions of Family and State, I9IS-I953, by Susan L. Glosser

6. An Artistic Exile: A Life of Feng Zikai (1898-1975), by Geremie R. Barmé

7. Mapping Early Modern Japan: Space, Place, and Culture in the Tokugawa Period, I603-I868, by Marcia Yonemoto

8. Republican Beijing: The City and Its Histories, by Madeleine Yue Dong

9. Hygienic Modernity: Meanings of Health and Disease in Treaty-Port China, by Ruth Rogaski

IO. Marrow of the Nation: A History of Sport and Physical Culture in Republican China, by Andrew D. Morris

II. Vicarious Language: Gender and Linguistic Modernity in Japan, by Miyako Inoue

I2. Japan in Print: Information and Nation in the Early Modern Period, by Mary Elizabeth Berry

I3. Millennial Monsters: Japanese Toys and the Global Imagination, by Anne Allison 


\title{
Vicarious Language
}

Gender and Linguistic Modernity in Japan

\author{
Miyako Inoue
}

UNIVERSITY OF CALIFORNIA PRESS

Berkeley / Los Angeles / London 
University of California Press, one of the most distinguished university presses in the United States, enriches lives around the world by advancing scholarship in the humanities, social sciences, and natural sciences. Its activities are supported by the UC Press Foundation and by philanthropic contributions from individuals and institutions. For more information, visit www.ucpress.edu.

Chapter I was previously published as "The Listening Subject of Japanese Modernity and His Auditory Double: Citing, Sighting, and Siting the Modern Japanese Woman," Cultural Anthropology i8 (3): 156-93, and is (C) 2003 by the American Anthropological Association. Chapter 2 was previously published as "Gender, Language, and Modernity: Toward an Effective History of Japanese Women's Language," American Ethnologist 29 (2): $392-422$, and is (C) 2002 by the American Anthropological Association.

University of California Press

Berkeley and Los Angeles, California

University of California Press, Ltd.

London, England

(C) 2006 by The Regents of the University of California

Library of Congress Cataloging-in-Publication Data

Inoue, Miyako, date.

Vicarious language : gender and linguistic modernity in Japan / Miyako Inoue.

p. $\quad \mathrm{cm}$. -(Asia-Local studies/global themes; II)

Includes bibliographical references and index.

ISBN 0-520-24584-9 (cloth : alk. paper)-ISBN 0-520-24585-7 (pbk. : alk. paper)

I. Women-Japan-Language. 2. Japanese language-Sex

differences. I. Title. II. Series.

PL698.W65I56 2006

306.44'082'0952-dc22

2005010545

Manufactured in the United States of America

$\begin{array}{llllllllll}\text { I4 } & \text { I3 } & \text { I2 } & \text { II } & \text { IO } & 09 & 08 & 07 & 06 & 05\end{array}$

IO $\quad 9 \begin{array}{lllllllll} & 9 & 7 & 6 & 5 & 4 & 3 & 2 & \text { I }\end{array}$

Printed on Ecobook 50 containing a minimum $50 \%$ post-consumer waste, processed chlorine free. The balance contains virgin pulp, including $25 \%$ Forest Stewardship Council Certified for no old growth tree cutting, processed either TCF or ECF. The sheet is acid-free and meets the minimum requirements of ANSI/NISO Z39.48-I992 (R I997)

(Permanence of Paper).@ 
This book is dedicated to

Kuniharu Inoue

Kazumi Inoue

This is my shinshoarikomachi! 
This page intentionally left blank 